\title{
Acute polymyositis during treatment of acute hepatitis C with pegylated interferon alpha-2b
}

\author{
G. Venezia, A. Licata, V. Di Marco, A. Craxì, P.L. Almasio* \\ Chair of Gastroenterology, University of Palermo, Palermo 90127, Italy
}

Received 11 November 2004; accepted 14 June 2005

Available online 15 September 2005

\begin{abstract}
Hepatitis $C$ virus is not cleared after primary infection in $50-85 \%$ of subjects exposed to hepatitis $C$ virus. Anti-viral treatment during the early phase of infection significantly enhances the likelihood of a sustained clearance of hepatitis $\mathrm{C}$ virus. Although, a variety of autoimmunerelated side effects have been observed during interferon therapy for chronic hepatitis, immuno-mediated adverse reactions have not been reported during treatment of acute hepatitis $\mathrm{C}$.

We describe the case of a patient who developed acute hepatitis $\mathrm{C}$ virus infection and, while receiving pegylated interferon alpha-2b monotherapy, developed a severe polymyositis. This case illustrates the potential risk of autoimmunity by interferon, also for acute hepatitis, and underlines the importance of a prompt diagnosis and a rapid discontinuation of interferon treatment for an improvement of clinical outcomes.
\end{abstract}

(C) 2005 Editrice Gastroenterologica Italiana S.r.1. Published by Elsevier Ltd. All rights reserved.

Keywords: Acute hepatitis C; Hepatitis C virus; IFN; Polymyositis

\section{Introduction}

Hepatitis $\mathrm{C}$ virus $(\mathrm{HCV})$ is not cleared after primary infection in $50-85 \%$ of subjects exposed to HCV [1-3], and evolves to significant chronic liver disease in up to $30 \%$ of subjects [4]. Recent meta-analyses [5-8] have clearly demonstrated that treatment with standard alpha-interferon (IFN- $\alpha$ ) during the early phase of infection significantly enhances the likelihood of a sustained clearance of HCV. Available data from the trials which specifically report on IFN-related side effects and adverse events [9-13] suggest that the tolerability of standard IFN in this context is good, and that side effects are uncommon although occasionally treatment has to be stopped. IFN is apparently tolerated by jaundiced patients also. Immuno-mediated adverse reactions and the occasional unmasking of autoimmune diseases have not been reported during treatment of acute hepatitis $\mathrm{C}$.

Pegylated IFNs (PEG-IFNs) $\alpha-2 \mathrm{a}$ and $\alpha-2 \mathrm{~b}$ in combination to ribavirin $[14,15]$ are currently considered the gold

\footnotetext{
* Corresponding author. Tel.: +39 091655 3131; fax: +39 0913552223.

E-mail address: palmasio@unipa.it (P.L. Almasio).
}

standard for chronic hepatitis $\mathrm{C}$ treatment, due to their more favourable efficacy and safety profile. Autoimmune-like reactions to PEG-IFNs in the pivotal trials have been equally uncommon than in the standard IFN comparator arms [16]. Although all data on treatment of acute hepatitis $\mathrm{C}$ concern the use of standard IFN, it is biologically and pharmacologically plausible that PEG-IFNs will be even more effective and have a better subjective tolerability in these patients. As a matter of fact, their off-label use for this indication has already started in some countries.

We therefore feel useful to call the physician's attention to a patient recently observed at our Unit, who developed acute $\mathrm{HCV}$ infection after cardiac catheterisation and, while receiving PEG-IFN- $\alpha-2 b$ monotherapy, developed a severe polymyositis.

\section{Case history}

A 51-year-old Caucasic man, without any history of exposure to drugs or toxins or significant alcohol abuse, was admitted to our Unit in May 2002 because of a 2-month 
history of severe asthenia and proximal muscle weakness associated to high values of alanine aminotransferase (ALT) [ $>10$ time upper limit of normal (uln)].

Ten months earlier, 40 days after a cardiac catheterisation for chest pain which showed no coronary hearth disease, he developed jaundice with ALT levels $20 \times$ uln. He was diagnosed as acute hepatitis $\mathrm{C}$, since anti-HCV and HCV-RNA were positive. HCV genotype tested at that time was $1 \mathrm{~b}$. Anti-HCV had been negative, and ALT normal, at the time of the catheterisation. HBsAg, anti-HBc IgM, anti-HAV IgM, anti-EBV IgM, anti-CMV IgM, anti-HIV, as well as creatinine phosphokinase levels, were and remained negative throughout the clinical course.

The patient was initially seen at an Infectious Disease Clinic and given treatment with PEG-IFN- $\alpha-2 b 80 \mu \mathrm{g} / \mathrm{week}$ s.c., starting on August 2001. Anti-nuclear and smooth muscle antibodies tested negative before treatment. ALT came into the normal range within 1 month, and serum HCVRNA was undetectable by PCR in January 2002. Treatment was reasonably well tolerated up to February 2002, when a de novo increase of ALT levels was found in association with appearance of progressive generalised weakness. This was considered to be a relapse of $\mathrm{HCV}$, and therefore PEGIFN was stopped in April 2002. Since severe asthenia and markedly raised ALT persisted, the patient was referred to our Unit on May 2002.

Physical examination showed a reduction of muscle strength, most evident in the proximal muscle girdle of the upper limbs with a relative sparing of the lower limbs. Laboratory tests showed normal white blood cells and platelets counts and a normal haemoglobin level. ESR was mildly raised and C-reactive protein and renal function tests normal. Serum enzyme profile was abnormal for AST $(10 \times$ uln $)$, ALT $(8 \times$ uln $)$, creatinine phosphokinase (10.519 IU/1; N.R. < $460 \mathrm{IU} / \mathrm{l})$ and lactic dehydrogenase (1385 IU/l; N.R. 130-460 IU/l). Serum HCV RNA was undetectable (Amplicor Monitor, Roche).

Immunological investigations showed the presence of anti-nuclear antibody positivity ('speckled pattern') with titration of $1 / 80$, with negative anti-extractable nuclear antigen antibodies (ENA), anti-neutrophil cytoplasmatic antibodies (ANCA) and anti-double stranded (DS) DNA antibodies. Anti-smooth muscle, mitochondrial and liver-kidney microsomal antibodies were negative. In spite of the presence of anti-peroxidase antibodies (TPO-ab) greater than $600 \mathrm{IU} / \mathrm{ml}$ (N.R. 0-34), thyroid function tests (T3, fT3, T4, fT4, TSH) were normal. HLA typing showed: A2, A32 (19), B7, B60 (40); DR11, open DR4, DR52, DQ (3).

An electromyography was performed and documented fibrillations and polyphasic motor unit potentials of low amplitude and short duration, suggestive of an inflammatory muscle disease. A muscle biopsy of the right deltoid showed an endomysial inflammatory infiltrate, degenerating and regenerating fibres, areas of muscle fibre necrosis and isolated atrophy (Fig. 1). A diagnosis of polymyositis secondary to PEG-IFN therapy was made, and treatment

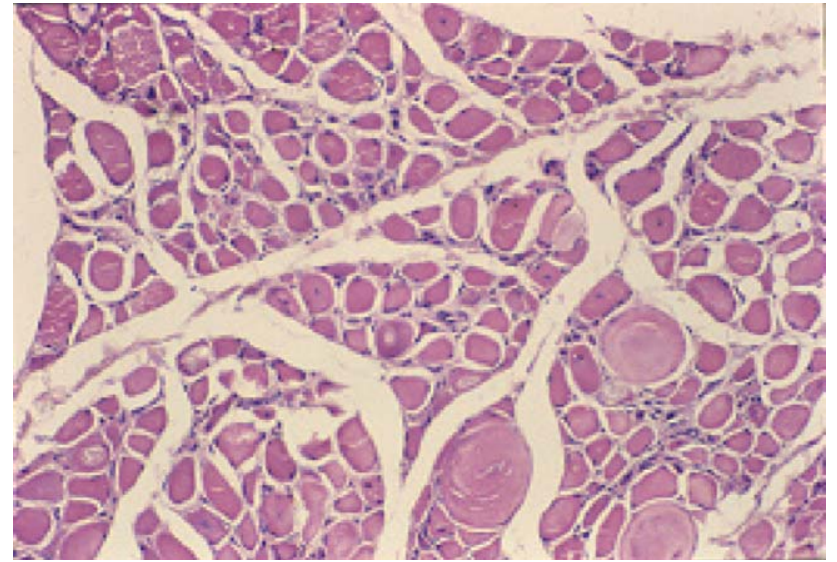

Fig. 1. Disruption of muscle fibres and the scattered inflammatory cells in the interstitium.

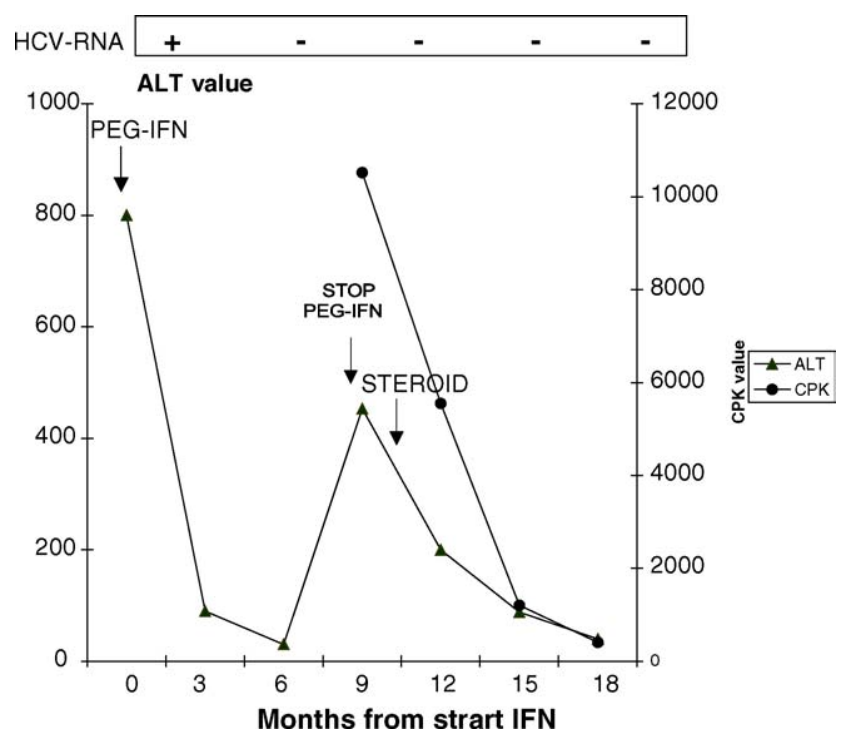

Fig. 2. Pattern of ALT and CPK values and HCV-RNA during and after IFN course.

with corticosteroids (metilprednisolone $1 \mathrm{mg} /(\mathrm{kg}$ die)) was started. After 3 months of steroids therapy, the patient had an improvement in subjective symptoms with decreases until normalisation of level of CPK, LDH and ALT (Fig. 2). HCV-RNA has remained persistently negative throughout steroid treatment up to the last follow-up visit.

\section{Discussion}

Polymyositis is a systemic autoimmune disorder characterised by proximal muscle weakness, which most frequently involves the limbs, neck and trunk [17]. In the literature there are some reports of $\mathrm{HCV}$ infection preceding or coincident with polymyositis [18-23]. However, while the association between HCV and mixed essential cryoglobulinemia, vasculitis, glomerulonephritis, autoimmune thyroid 
diseases is well established, the casual relationship with other autoimmune diseases such as polymyositis is still uncertain.

Few reports on development of polymyositis associated with IFN therapy have been described as a complication during treatment for malignancies or viral infections (HCV, HBV) [23-32]. Although HCV itself might cause polymyositis, it is unlikely that in our patient the disease was virus-related considering the temporal sequence of events. Our patient had no muscular symptoms in the initial phase of viral infection, but polymyositis developed well after starting IFN treatment at a time when HCV-RNA was undetectable. Furthermore, when IFN was withdrawn and steroid treatment instituted, there was a rapid improvement of subjective symptoms with normalisation of CPK, LDH and ALT. Ultimately, the detection of a typical EMG pattern and of features of inflammation on muscle biopsy confirmed the diagnosis of 'classic' polymyositis.

One word of caution should be paid for starting treatment soon after the beginning of symptoms of acute hepatitis C. According to Gerlach et al.'s paper [33] and a recent meta-analysis [8], more than half of patients will completely recover from acute $\mathrm{HCV}$ infection within 3 months from the onset of symptoms and therefore the anti-viral therapy could be further delayed without any relevant consequences on progression to chronicity.

Since the IFN is able to enhance expression of MHC class I antigens and promotes the production of proinflammatory cytokines such as IL-1 and TNF- $\alpha$ [34], these immunomodulatory effects either alone or in combination are most likely responsible for the autoimmune side effects and in polymyositis for muscle damage. Moreover, TNF- $\alpha$ may also participate in the initial phase of muscle damage as evidenced by selective increase of TNF- $\alpha$ mRNA and protein in the $\mathrm{CD} 8+$ autoinvasive $\mathrm{T}$ cells around the non-necrotic muscle fibres [35].

It is to note that the standard side effects of IFN therapy resemble symptoms of autoimmune diseases and this feature may make prompt diagnosis difficult. Therefore, it is important that autoimmune diseases such as polymyositis are recognised as potential side effects of treatment with IFN. The reports of polymyositis associated with IFN therapy showed that after discontinuation of IFN and institution of immunosuppressive treatment, the muscular weakness gradually recovered and the muscle enzyme values decreased. Thus, a prompt diagnosis and a rapid discontinuation of IFN treatment in association with steroid therapy can induce an improvement of clinical outcomes and complete remission of the disease. However, very recent reports have shown the relative benign course of IFN-induced polymyositis that might spontaneously resolve after IFN discontinuation requiring immunosuppressive therapy only in severe forms $[36,37]$. Finally, we think that creatinine phosphokinase levels should always be checked in patients with viral response but still with persistently abnormal transaminases.

\section{Conflict of interest statement}

None declared.

\section{References}

[1] Marcellin P. Hepatitis C, clinical spectrum of the disease. J Hepatol 1999;31(Suppl. 1):9-16.

[2] Orland JR, Wright TL, Cooper S. Acute hepatitis C. Hepatology 2001;33:321-7.

[3] Santantonio T, Sinisi E, Guastadisegni A, Casalino C, Mazzola M, Gentile A, et al. Natural course of acute hepatitis C: a long-term prospective study. Dig Liver Dis 2003;35:104-13.

[4] Hu KQ, Tong MJ. The long-term outcomes of patients with compensated hepatitis $C$ virus-related cirrhosis and history of parenteral exposure in the United States. Hepatology 1999;29:1311-6.

[5] Cammà C, Almasio $\mathrm{P}$, Craxì A. Interferon as treatment for acute hepatitis C. A meta-analysis. Dig Dis Sci 1996;41:124855 .

[6] Thevenot T, Regimbeau C, Ratziu V, Leroy V, Opolon P, Poynard $\mathrm{T}$. Meta-analysis of interferon randomized trials in the treatment of viral hepatitis C in naive patients: 1999 update. J Viral Hepat 2001;8:48-62.

[7] Poynard T, Regimbeau C, Myers RP, Thevenot T, Leroy V, Mathurin P, et al. Interferon for acute hepatitis C. Cochrane Database Syst Rev 2002;(1):CD000369.

[8] Licata A, Di Bona D, Schepis F, Shahied L, Craxì A, Camma C. When and how to treat acute hepatitis C? J Hepatol 2003;39:1056-62.

[9] Viladomiu L, Genesca J, Esteban JI, Allende H, Gonzalez A, LopezTalavera JC, et al. Interferon-alpha in acute posttransfusion hepatitis C: a randomized, controlled trial. Hepatology 1992;15:767-9.

[10] Tassopoulos NC, Koutelou MG, Papatheodoridis G, Polychronaki H, Delladetsima I, Giannikakis T, et al. Recombinant human interferon alfa- $2 \mathrm{~b}$ treatment for acute non-A, non-B hepatitis. Gut 1993;34:S130-2.

[11] Palmovic D, Kurelac I, Crnjakovic-Palmovic J. The treatment of acute post-transfusion hepatitis $\mathrm{C}$ with recombinant interferon-alpha. Infection 1994;22:222-3.

[12] Hwang SJ, Lee SD, Chan CY, Lu RH, Lo KJ. A randomized controlled trial of recombinant interferon alpha- $2 b$ in the treatment of Chinese patients with acute post-transfusion hepatitis C. J Hepatol 1994;21:831-6.

[13] Calleri G, Colombatto P, Gozzelino M, Chieppa F, Romano P, Delmastro B, et al. Natural beta interferon in acute type-C hepatitis patients: a randomized controlled trial. Ital J Gastroenterol Hepatol 1998;30:181-4

[14] Manns MP, McHutchison JG, Gordon SC, Rustgi VK, Shiffman M, Reindollar R, et al. Peginterferon alfa- $2 \mathrm{~b}$ plus ribavirin compared with interferon alfa- $2 \mathrm{~b}$ plus ribavirin for initial treatment of chronic hepatitis C: a randomised trial. Lancet 2001;358:958-65.

[15] Fried MW, Shiffman ML, Reddy RK, Smith C, Marinos G, Goncales Jr FL, et al. Peginterferon alfa-2a plus ribavirin for chronic hepatitis C virus infection. N Engl J Med 2002;347:975-82.

[16] Fried MW. Side effects of therapy of hepatitis C and their management. Hepatology 2002;36:S237-44.

[17] Dalakas MC, Hohlfeld R. Polymyositis and dermatomyositis. Lancet 2003;362:971-82.

[18] Satoh J, Eguchi Y, Narukiyo T, Mizuta T, Kobayashi O, Kawai M, et al. Necrotizing myopathy in a patient with chronic hepatitis $\mathrm{C}$ virus infection: a case report and a review of the literature. Intern Med 2000;39:176-81.

[19] Sola P, Galassi G, Merelli E, Ferrari MG, Sorgato P, Ghini M. Detection of $\mathrm{HCV}$-specific sequences in chronic myopathy with hepatitis $\mathrm{C}$ : improvement with interferon-alpha $2 \mathrm{~A}$ therapy. Eur Neurol 1999;42:181-3. 
[20] Di Muzio A, Bonetti B, Capasso M, Panzeri L, Pizzigallo E, Rizzuto $\mathrm{N}$, et al. Hepatitis $\mathrm{C}$ virus infection and myositis: a virus localization study. Neuromuscul Disord 2003;13:68-71.

[21] Horsmans Y, Geubel AP. Symptomatic myopathy in hepatitis C infection without interferon therapy. Lancet 1995;345:1236.

[22] Alric L, Partensky J, Reynaud D, Rauzy O, Duffaut M. Association between polymyositis and hepatitis $\mathrm{C}$ infection. Treatment-related difficulties. Rev Med Interne 2000;21:542-6.

[23] Dietrich LL, Bridges AJ, Albertini MR. Dermatomyositis after interferon alpha treatment. Med Oncol 2000;17:64-9.

[24] Kalkner KM, Ronnblom L, Karlsson Parra AK, Bengtsson M, Olsson Y, Oberg K. Antibodies against double-stranded DNA and development of polymyositis during treatment with interferon. Q J Med 1998;91:393-9.

[25] Matsuya M, Abe T, Tosaka M, Yonezawa K, Ono A, Ikeda N, et al. The first case of polymyositis associated with interferon therapy. Intern Med 1994;33:806-8.

[26] Schleinitz N, Veit V, Labarelle A, Figarella-Branger D, Harle JR. Polymyositis: a rare complication of interferon alpha therapy. Rev Med Interne 2000;21:113-4.

[27] Lee SW, Kim KC, Oh DH, Jung SS, Yoo DH, Kim SY, et al. A case of polymyositis with dilated cardiomyopathy associated with interferon alpha treatment for hepatitis B. J Korean Med Sci 2002;17:141-3.

[28] Cirigliano G, Della Rossa A, Tavoni A, Viacava P, Bombardieri S. Polymyositis occurring during alpha-interferon treatment for malignant melanoma: a case report and review of the literature. Rheumatol Int 1999;19:65-7.

[29] Arai H, Tanaka M, Ohta K, Kojo T, Niijima K, Imawari M. Symptomatic myopathy associated with interferon therapy for chronic hepatitis C. Lancet 1995;345:582.
[30] Sato Y, Takatsu Y, Yamada T, Kataoka K, Taniguchi R, Mimura R, et al. Interferon treatment for dilated cardiomyopathy and striated myopathy associated with hepatitis $\mathrm{C}$ virus infection based on serial measurements of serum concentrations of cardiac troponin T. Jpn Circ J 2000;64:321-4.

[31] Falcone A, Bodenizza CA, Musto P, Carotenuto M. Symptomatic myopathy during interferon alfa therapy for chronic myelogenous leukaemia. Leukemia 1998;12:1329.

[32] Iguchi H, Kishi M, Fujioka T, Wakata N, Kinoshita M. Polymyositis after interferon beta treatment of chronic hepatitis type C. Rinsho Shinkeigaku 1996;36:22-4.

[33] Gerlach JT, Diepolder HM, Zachoval R, Gruener NH, Jung MC, Ulsenheimer A, et al. Acute hepatitis C: high rate of both spontaneous and treatment-induced viral clearance. Gastroenterology 2003;25:80-8.

[34] Dumoulin FL, Leifeld L, Sauerbruch T, Spengler U. Autoimmunity induced by interferon- $\alpha$ therapy for chronic viral hepatitis. Biomed Pharmacother 1999;53:242-54.

[35] Kuru S, Inukai A, Liang Y, Doyu M, Takano A, Sobue G. Tumornecrosis factor- $\alpha$ expression in muscles of polymyositis and dermatomyositis. Acta Neuropathol 2000;99:585-8.

[36] Golstein PE, Delforge ML, Deviere J, Marcellin P. Reversible myopathy during successful treatment with pegylated interferon and ribavirin for acute hepatitis C. J Viral Hepat 2004;11:183-6.

[37] Curry MP, Robinson SC, Savitz S, Williams C, Gitlin N. Elevated ALT and AST due to pegylated interferon $-\alpha$ induced polymyositis in treated patients with undetectable hepatitis $\mathrm{C}$ viral load. Hepatology 2004;40(Suppl. 1):344A. 